\title{
WOLF V. COLORADO AND UNREASONABLE SEARCH AND SEIZURE IN CALIFORNIA
}

The United States Supreme Court, in Wolf v. Colorado, ${ }^{1}$ held for the first time that "the security of one's privacy against arbitrary intrusion by the police-which is at the core of the Fourth Amendment" 2-is, in the language of Palko v. Connecticut, implicit in "the concept of ordered liberty" and hence protected against state action by the due process clause of the Fourteenth Amendment. ${ }^{4}$ But at the same time the Court held that the states need not observe the federal rule which excludes from criminal prosecutions evidence obtained by illegal search. ${ }^{5}$ The majority opinion explamed away the federal exclusionary rule as "judicial implication" based upon the Fourth Amendment, while Justice Black, in a concurring opinion, characterized the rule as a "judicially created rule of evidence," a description which seems more consistent with the Court's suggestion that it could be changed by Congress. ${ }^{\circ}$

The decision makes it plain that the federal law of search and seizure is not to be applied to the states in its entirety but is to be classified into (1) constitutional rules and (2) federal rules of "procedure" or "evidence" such as the exclusionary rule. Only the constitutional rules bind the states. However, if the exclusionary rule is the only effective means for enforcing the guarantee, the Court has proclaimed an illusory right. This comment will examine the California and federal law of search and seizure to determine whether the state gives a substantive right when constitutionally required, and if so,

1338 U.S. 25 (1949). See Allen, The Wolf Case: Search and Seizure, Federalism, and the Civil Liberties, 45 Ir工. L. REv. 1 (1950); Rudd, Present Significance of Constitutional Guaranties against Unreasonable Searches and Seizures, 18 U. of Cox. L. REv. 387 (1949); Notes, 30 B. U. L. REv. 110 (1950), 48 MrCH. L. REv. 118 (1949), 25 N. Y. U. L. Q. REV. 168 (1950).

2 "The right of the people to be secure in their persons, houses, papers, and effects, against unreasonable searches and seizures, shall not be violated; and no warrants shall issue, but upon probable cause, supported by oath or affirmation, and particularly describing the place to be searched, and the persons or things to be seized."

3302 U. S. 319 (1937).

4 The entire court agreed upon this point. Justices Murphy, Rutledge, and Douglas, dissenting, and Justice Black, concurring, beheved that the Fourth Amendment should be automatically incorporated into the Fourteenth. Cf. Adams v. New York, 192 U. S. 585 (1904) where the question of the application of the Fourth Amendment to the states was expressly reserved.

5 Silverthorne Lumber Co. v. United States, 251 U. S. 385 (1920), 8 CarrF. L. REv. 347 (1920); Weeks v. United States, 232 U. S. 383 (1914); Boyd v. United States, 116 U. S. 616 (1886). See generally 8 WIGMORE, EvIDENCE $\$ \S 2183,2184,21843,2264$ (3rd ed. 1940) ; Kidd, Some Recent Cases in Evidence, 13 CAr.T. I. Rev. 285, 293 (1925); Grant, Circumventing the Fourth Amendment, 14 So. CaxIF. L. Rev. 359, 372 (1941).

6 The dissent objected that even if the exclusionary rule was not part of the Fourth Amendment, it implemented the "concept of ordered liberty" and was therefore part of the Fourteenth. 
whether remedies exist which make the right real. The inquiry is twofold:

1. In what areas may federal constitutional doctrine import into state law a different standard of unreasonable search and seizure? ${ }^{7}$

2. Assuming an unreasonable search and seizure has occurred, what remedies are available to moderate the effects in a criminal prosecution of a seizure of evidence, to provide redress and to punish the offender?

\section{WHAT IS AN UNREASONABLE SEARCH AND SEIZURE IN CALIFORNIA?}

Although what is "unreasonable" official search and seizure is now a federal question, ${ }^{8}$ the act of a state officer which does not meet the standards set by prior federal cases is not ipso facto "unreasonable." Only those federal precedents which announce "constitutional" rules require conformity of state procedures. Unfortunately, the nature of almost all the federal rules in this field is a matter of speculation. The validity of several Califorma procedures will now be considered, in the light of the dual character of the federal precedents.

\section{Evidence of Probable Cause}

To establish probable cause for the issuance of a search warrant, the federal rule requires evidence properly admissible in a trial of the offense concerned, while in California, relevant, though inadmissible evidence is probably sufficient. ${ }^{9}$ If this federal rule, like the exclusionary rule, is simply a "rule of evidence," the California practice is constitutional. But as the evidence upon which the warrant is based determines the very reason for the search in an ex parte proceeding, this federal rule could be a substantive constitutional guarantee superseding California law.

T This comment will consider search and seizure only in connection with criminal cases. Neither subpoenas duces tecum nor administrative agency orders for the production of books and papers will be considered.

\& Cf. Lisenba v. California, 314 U. S. 219, 236 (1941) (self-incrimination): "The Fourteenth Amendment leaves California free to adopt, by statute or decision, and to enforce such rule as she elects, whether it conform to that applied in the federal or in other state courts. But the adoption of the rule of her choice cannot foreclose inquiry as to whether, in a given case, the application of that rule works a deprivation of the prisoner's life or liberty without due process of law." But cf. dissent of Justice Black in United States v. Rabinowitz, $\longrightarrow$ U. S. $\longrightarrow, 70$ S. Ct. 430, 444 (1950), citing the Wolf case for the proposition that the definition of unreasonableness is inere federal judicial policy and not a constitutional question. The Wolf case, however, was not attempting to define "unreasonable" search and seizure.

9 Grant, Search and Seizure in California, 15 So. Carr. I. REv. 139, 143-144 (1942). 


\section{Seizure for Evidentiary Purposes Only}

The federal rule that any warrant is invalid when issued to seize property desired only as evidence ${ }^{10}$ is probably a "rule of procedure" rather than a "constitutional" limitation on the states, in view of the policy of allowing them a reasonable selection of criminal procedures. ${ }^{11}$ California law, however, apparently meets the standards set by the federal rule; seizure solely for evidentiary purposes is not provided for in the Penal Code. ${ }^{12}$

\section{"John Doe" Warrants}

In federal law a person and his surroundings may, within certain limits, be searched after a valid arrest ${ }^{13}$ and, in the absence of a federal statute, the validity of the arrest is governed by state law. ${ }^{14}$ But the language in Wolf $v$. Colorado which would protect "the security of one's privacy," refers equally to the guarantee against unreasonable arrest which is provided by the Fourth Amendment. ${ }^{16}$ Thus, state arrest procedures must meet certain minimum federal standards to be valid. By federal law, arrests upon "John Doe" warrants, in which a fictitious name is used to indicate the person to be arrested, are forbidden by the Fourth Amendment. ${ }^{18}$ California Penal Code section 815 authorizes such arrests. ${ }^{15}$ As the lawfulness of an arrest

10 See United States v. Rabinowitz, U.S. 70 S. St. 430,434 n. 6 (1950) ; Harris v. United States, 331 U. S. 145, 154 (1947); United States v. Lefkowitz, 285 U. S. 452, 464-465 (1932); Grant, Circumventing the Fourth Amendment, 14 So. CAIIF. L. REv. 359, 363 (1941).

11 E.g., Adamson v. California, 332 U.S. 46 (1947); Palko v. Connecticut, supra note 3; Brown v. Mississippi, 297 U.S. 278, 285 (1936); Twining v. New Jersey, 211 U.S. 78 (1908); Hurtado v. California, 110 U.S. 516 (1884).

${ }^{12}$ Cf. Stern v. Superior Court, 76 Cal. App. 2d 772, 174 P. $2 d 34$ (1946) (seizure of currency in prosecution for crime of abortion held illegal). CAL. PEN. CODE § 1524(2), allowing seizure of property "used as the neans of conmitting a felony" does not contravene the rule, for, in federal law, the instrumentalities by which tbe crime was committed can be searched for and seized. See Harris v. U.S., supra note 10 at 154.

13 United States v. Rabinowitz, supra note 10. In California limited search of the person of the arrested suspect is authorized by CAL. PEN. CODE $\$ \$ 846$ (right to take weapons), 1542 (right to take weapons or other evidentiary nuatter upon direction of magistrate). This search is allowed to extend to articles needed for evidentiary purposes only. Cal. Pen. Code \& 1412. Cf. People v. Winthrop, 118 Cal. 85, 91, 50 Pac. 390, 392 (1897). See generally Grant, supra note 9, 140-141.

14 United States v. Di Re, 332 U. S. 581 (1948); Johnson v. United States, 333 U. S. 10 (1948) ; Dorsey v. United States, 174 F. 2d 899 (5th Cir. 1949).

15 West v. Cabell, 153 U. S. 78 (1894). Accord, construing similar section Car. Const. Art. I, § 19, In re Be Hoe, 1 Labatt's District Court Reports 204 (1857).

${ }_{16}$ West v. Cabell, supra note 15. Cf. Lee Gim Bor v. Ferrari, 55 F. 2nd 86 (1st Cir. 1932) ; Duffy v. Keville, 16 F. $2 d 828$ (D. C. Mass. 1926) ; United States v. Doe, 127 Fed. 982 (N. D. Calif. 1904). See United States v. Eighteen Cases of Tuna Fish, 5 F. 2d 979 (W.D. Va. 1925). But see United States v. Borkowski, 268 Fed. 408, 411 (S.D. Ohio 1920).

17 CAL. PEN. CODE $§ 815$. "The warrant inust specify the naune of the defendant, or, if it is unknown to the nuagistrate, the defendant may be designated therein by any 
determines whether or not an attendant search is "reasonable," 18 Wolf v. Colorado may not only invalidate an arrest under a "John Doe" warrant, but by making the arrest illegal, also invalidate the search and seizure.

\section{Scope of Search Incident to a Valid Arrest}

Although recent United States Supreme Court decisions show considerable fluctuation, ${ }^{19}$ at present an arresting federal officer without a search warrant may search as much of a dwelling or place of business as meets all of the following requirements: (1) the crime must be in process of being committed there; ${ }^{20}$ (2) the area searched must be under the control of the suspect; ${ }^{21}$ (3) the search must be contemporaneous with a valid arrest of the suspect upon the premises. ${ }^{22}$ California law appears to observe these standards; ${ }^{23}$ thus,

name. . . " In Elliott v. Haskins, 20 Cal. App. 2d 591, 67 P. $2 d 698$ (1937), this section was upheld over constitutional objections. As the case assumed that U. S. CoNsT. Arrend. IV did not apply to the states, it is now of questionable authority. Contra: In re Schaefer, 134 Cal. App. 498, 25 P. 2d 490 (1933), not mentioned in the Elliot case. The Schaefer decision held the section repugnant to Cat. Const. Art I, $\S 19$, which is substantially similar in wording to U. S. CoNST. AMrEND. IV. See Grant, supra note 9, 141142. However, the word "designate" in the code section should be interpreted to mean that the individual to be arrested need be only sufficiently described, as, for example, "Mary Doe (fictitious), Joln Smith's secretary."

18 United States v, Rabinowitz, supra note 10 (general search of office held valid when proprietor arrested there upon vahid warrant). Cf. McDonald v. United States, 335 U. S. 451 (1948) (illegal entry on premises-resulting arrest and the search and seizure incident thereto invalid); Johnson v. United States, 333 U.S. 10 (1948) (search of room without warrant held invalid when no probable cause for arrest of the particular individual occupying the room); United States v. Di Re, 332 U.S. 581 (1948) (search of car without warrant invalid when no probable cause for arrest of passenger); Harris v. United States, 331 U. S. 145 (1947) (general search of apartment upheld upon a valid arrest of the occupant). An arrest may not be used solely as a pretext for a search and seizure. United States v. Lefkowitz, supra note 10; Go-Bart Importing Co. v. United States, 282 U. S. 344 (1931). Cf. Harris v. United States, supra at 153.

19 In 1947 the Court (5-4) allowed a general search of an apartment incident to a valid arrest. Harris v. United States, supra note 18. One year later Harris was distinguished in Trupiano v. United States, 334 U.S. 699 (1948) as the Court held invalid (5-4) a search and seizure, upon valid arrest, of readily observable articles in a barn. After only two years, the Court, changed in personnel, overruled Trupiano in so far as it required a search warrant whenever reasonably obtainable, and returned (5-3) to the Harris rule, noting that the unreasonableness of a search and seizure depends upon the circumstances of each case. United States v. Rabinowitz, supra note 10.

20 In United States v. Rabinowitz, supra note 10, and Harris v. Umited States, supra note 10, possession of the matter seized constituted the crime. The Rabinovitz court, however, recognized that inerely evidentiary materials are not properly subject to seizure. Text at note 10.

21 See United States v. Rabinowitz, supra note 10 at 433.

22 Id.; Agnello v. United States, 269 U. S. 20, 30 (1925).

23 Collins v. Lean, 68 Cal. 284, 9 Pac. 173 (1885) (upon an arrest, search of shop for lottery tickets upheld when warrant was only for a search of the person of the suspect); Bruce v. Sibeck, 25 Cal. App. 2d 691, 78 P. 2d 741 (1938), hecring denied (upon valid arrest, seizure without warrant of fishing and boating equipment in possession of 
even if these criteria are constitutional limitations, state law on this subject will, in all probability, remain unchanged.

\section{REMEDIES ${ }^{24}$}

\section{The Federal "Civil Rights Acts"}

As Wolf v. Colorado incorporates the Fourth Amendment into the due process clause,$^{25}$ a federal right protected against state action has been created..$^{26}$ Although it was once believed that "state action" did not result if the acts of officers were unauthorized or forbidden by state law, ${ }^{2 \pi}$ it is now settled that any conduct by an officer purporting to exercise state power can be "state action." ${ }^{8}$ The question here is whether a victim of an unreasonable official search and seizure is entitled to enforcement of his rights in the federal courts under the

suspect fishermen upheld). This case found a broad right to seize goods which must be preserved for forfeiture to the state.

Cahifornia law generally meets federal standards of specificity for search warrants. Atlas Fimance Corp. v. Kenny, 68 Cal. App. 2d 504, 157 P. 2d 401 (1945); People v. Mayen, 188 Cal. 237, 205 Pac. 435 (1922).

24 CAL. Crv. Code $\S 50$ and CAL. PEN. CODE $\$ \S 692$ and 694 allow the use of force to prevent invasions of rights, including illegal searches and seizures. People v. Rose, 19 Cal. App. 469, 126 Pac. 375 (1912). Such self-help, a remedy of doubtful practicality, is outside the scope of this comment. CAL. PEN CODE $\S 102$, making the taking of personal property held by an officer under process of law a misdemeanor, puts a risk upon one who resists. See Yankwich, Lazwless Enforcement of the Law, 9 So. CaLTr. L. REv. 14, 19-21 (1935) for the conclusion that courts are very solicitous to protect police officers for their well-intentioned acts.

25 Text at note 4, supra.

26 State action is required if there is a federal right to be protected under the Fourteenth Amendment. Civil Rights Cases, 109 U. S. 3 (1883); Hardyman v. Collins, 80 F. Supp. 501 (S. D. Calif. 1948). Cf. Bell v. Hood, 71 F. Supp. 813 (S. D. Calif. 1947).

2r Memphis v. Cumberland T. \& T. Co., 218 U.S. 624 (1910) ; Barney v. New York, 193 U. S. 430 (1904). The search and seizure provision of CaI. Const. Art. I, \& 19 being substantially identical to the federal provision, this theory would preclude an unreasonable search and seizure from being state action. Shanks v. Banting Mfg. Co., 9 F. 2d 116 (N. D. Ohio 1925).

28 Screws v. United States, 325 U. S. 91 (1945); Mooney v. Holohan, 294 U. S. 103 (1935) ; Iowa-Des Moines Bank v. Bennett, 284 U. S. 239 (1931); Home T. \& T. Co. v. Los Angeles, 227 U. S. 278 (1913); Raymond v. Chicago Traction Co., 207 U. S. 20 (1907) ; Ex parte Virginia, 100 U. S. 339 (1879); Picking v. Pennsylvania R. R., 151 F. 2d 240 (3rd Cir. 1945) ; United States v. Trierweiler, 52 F. Supp. 4 (E. D. II. 1943); United States v. Sutherland, 37 F. Supp. 344 (N. D. Ga. 1940). Cf. Ex parte Young, 209 U. S. 123 (1908), holding that although a suit to enjoin official acts is not an action against the state under the 11 th Amendment, the acts are state action for the purpose of a suit in equity under the 14th Amendment. That the officer misuses statutory power is enough-the wrong need not be one that was possible only through the exercise of state authority. United States v. Trierweiler, supra. But cf. Brawner v. Irvin, 169 Fed. 964 (C. C. N. D. Ga. 1909), probably now of questionable persuasiveness. Also see dissent of Justice Frankfurter in Snowden v. Hughes, 321 V. S. 1, 16 (1944) that every state officer who wields state power is not necessarily acting for the state. 
poorly integrated civil ${ }^{29}$ and criminal ${ }^{30}$ statutes known as the "Civil Rights Acts." 31

\section{Section 242 of the Criminal Code ${ }^{32}$ provides:}

Whoever, under color of any law, statute, ordinance, regulation, or custom, willfully subjects any inhabitant . . . to the deprivation of any rights, privileges, or immunities secured or protected by the Constitution or laws of the United States, . . . shall be fined not more than $\$ 1,000$, or imprisoned not more than one year, or both. ${ }^{33}$

The two problems which arise most frequently in the application of this statute are (1) what acts are committed under "color of law" and (2) what acts can, consistently with the notice requirement of due process, be punished.

The statutory requirement of "color of law" is analogous to the constitutional requirement of "state action" in requiring "(m) isuse of power, possessed by virtue of state law and made possible only because the wrongdoer is clothed with the authority of state law ${ }^{34}$. . ." An unreasonable search and seizure, even though an act expressly forbidden by state law, probably satisfies the requirement that the act must be "under color of law." Although courts tend to confound "color of law" with the "state action" limitation, ${ }^{35}$ it recently received lengthy independent discussion in two Supreme Court cases ${ }^{36}$ which determined that acts of state officers who violate state law can still be said to be under "color of law." ${ }^{37}$ There is a possibility, however,

2028 U. S. C. $\S 1343$ (1948) does not require any jurisdictional amount for suit in the federal district courts in civil rights cases. See BUNN, JURISDICTION AND PRACTICE OF THE COURTS OF THE UNTTED STATES 77-80 (1949).

30 The location of a federal criminal prosecution would not vary significantly from one in the state courts since a federal offense must be tried by a jury of the state and district where the crime was committed. U.S. ConST. AMrEND. VI. The most important advantage in crimimal cases would be, in some instances, a inore diligent prosecution of the state officers concerned. E.g., Screws v. United States, supra note 28; United States v. Cowan (Dept. of Justice, Division of Commumications and Records, Case No. 144-324), cited in Carr, Federal Protection of Civil Righrs 86 (1947). But close liaison with state officers may also deter a federal prosecution.

31 See CARR, op. cit. supra note 30, at 35-47, for the large scope of the original civil rights program in the decade following the Civil War. Hostility by the courts, which declared several of the statutes unconstitutional, and by later Congresses, which repealed many more, has left only fragmentary remains.

3218 U. S. C. $\$ 242$ (1948). Before the adoption of the new Criminal Code in 1948, this section was 16 StAx. 144 (1870), as amended, 18 U. S. C. $\$ 52$ (1946).

33 See note 52, infra, for a discussion of the punishment.

34 United States v. Classic, 313 U. S. 299, 326 (1941).

35 E.g., United States v. Sutherland, 37 F. Supp. 344 (N.D. Ga. 1940).

36 United States v. Classic, supra note 34 (fraudulent counting of votes by election officials); Screws v. United States, 325 U. S. 91 (1945) (Inurder by sheriff in performing arrest).

${ }^{37}$ Accord, Crews v. United States, 160 F.2d 746 (5th Cir. 1947) (constable murdering for a private grudge but purporting, by oral declarations, to act as an officer); McShane v. Moldovan, 172 F. 2d 1016 (6th Cir. 1949); Williams v. United States, 179 F. 2d 656 (5th Cir. 1950). See Catlette v. United States, 132 F. 2d 902 (4th Cir. 1943) for the proposition that non-action by a state officer can be pumshed under this section.

See Screws v. United States, supra note 36, dissent at 138, for a violent attack on this view. Justice Frankfurter was reputedly the author of the opinion. CARR, op. cit. 
that the "color of law" requirement may be more restrictive than "state action." Justices Frankfurter and Jackson hold this view and have specifically indicated that they exclude illegal searches and seizures by state officers from the scope of the statute. ${ }^{38}$

A most difficult Fifth Amendment due process problem in applying this statute to illegal searches and seizures is the vagueness of a crime defined as depriving a person of rights protected by the Constitution or laws of the United States. ${ }^{29}$ In the Screws case ${ }^{40}$ the Court wrestled with this question, four justices ${ }^{41}$ seizing on the word "willfully" to create a requirement that one must be considered chargeable with notice ${ }^{42}$ of what had previously been "made specific either by the express terms of the Constitution or laws of the United States or by decisions interpreting them." 43 Thus, Wolf $v$. Colorado ${ }^{44}$ may classify freedom from unreasonable search and seizure as a "specific" constitutional right and charge state officers with notice. ${ }^{45}$ However, Justices Frankfurter, Roberts, and Jackson have indicated a strong belief that the entire statute is void for vagueness. ${ }^{40} \mathrm{With}$ the recent change in Court personnel, the constitutionality of the statute as applied to any of the due process rights is in doubt.. ${ }^{47}$

supra note 30 , at $111 \mathrm{n} .46$. Also see $i d$. at $113-114$ for the wavering of the members of the Court on this issue in the Classic and Screws cases-five members of the court changed their positions in the second case, three of them joining the majority and two going over to the dissent.

38 Screws v. United States, supra note 28, dissent at 139, 144. Compare Justice Frankfurter's position on the analogous constitutional issue of state action, stipra note 28.

39 A statute must give fair notice of acts prohibited if it is to meet the requirements of the due process clause of the Fifth Amendment. United States v. Cohen Grocery Co., 255 U. S. 81 (1921). See Note, 30 CALIF. L. REv. 677 (1942) for limitations on the Cohen doctrine. Cf. Winters v. New York, 333 U. S. 507 (1948).

40 Supra note 28.

41 Opinion by Justice Douglas, concurred in by Chief Justice Stone, Justice Black, and Justice Reed. There was no majority opinion.

${ }_{42}$ The requirement seems not to be one of actual notice, for the Douglas opinion at 325 U. S. 104 suggests that "reckless disregard" of a defined constitutional or statutory prohibition will suffice. This allows a more workable application of the statute to acts of public officers.

$43325 \mathrm{U}$. S. at 104 . If the theories held by Justice Black were followed, there would be a specific guarantee against unreasonable search and seizure by incorporation of the Fourth Amendment into the Fourteenth. See his concurring opinion in Wolf v. Colorado, 338 U. S. at 39 (1949) and his long dissent in Adamson v. California, 332 U. S. at 68 (1947).

44 Supra note 1.

45 How "specific" is the guarantee against unreasonable search and seizure, or, for that matter, any of the due process rights? Sce the difference of opinion in Wolf $v$. Colorado, sutpra at note 6 as to what a "specific" guarantee includes.

${ }_{46} 325 \mathrm{U}$. S. at 138. Justices Rutledge and Murphy, in separate opinions, indicated that they believed that the problem did not arisc, at least when the act of the public officers was a flagrant deprivation of a well-recognized right under the 14th Amendment, such as the right not to be beaten to death, the issue in the Screws case.

47 In Crews v. United States, supra note 37, conviction under the statute of a constable for acts (murder of prisoner) similar to those involved in the Screwes case was upheld, when proper instructions had been given. $C f$. Pullen v. United States, 164 F. 2d 75 (5th Cir. 1947). 


\section{Section 241 of the Criminal Code $^{48}$ provides:}

If two or more persons conspire to injure, oppress, threaten, or intimidate any citizen in the free exercise or enjoyment of any right or privilege secured to him by the Constitution or laws of the United States, or because of his having so exercised the same; ... They shall be fined not more than $\$ 5,000$ or imprisoned not more than ten years, or both.

Although this statute does not require that acts be under "color of law," its weaknesses are numerous. ${ }^{49}$ It is limited to conspiracies; ${ }^{50}$ it protects only citizens; ${ }^{51}$ its penalties are so severe that a jury may be reluctant to convict. ${ }^{52}$

Because the section does not in terms punish only "willful" misconduct, ${ }^{53}$ it raises a serious vagueness question. ${ }^{54}$ However, if it would be sufficient to save the section from unconstitutionality, it would seem proper in view of the history of these statutes to read in a requirement of "willful" misconduct to make the section consistent with Section $242 .{ }^{55}$ Mimor differences in wording im sections of diverse origin should not be allowed to defeat their broad purpose..$^{56}$

4818 U. S. C. $\$ 241$ (1948). Before the adoption of the New Criminal Code in 1948, this section was 16 STAT. 141 (1870), as amended, 18 U. S. C. $\$ 51$ (1946).

${ }^{49}$ See CARR, op. cit. supra note 30, 58-60.

50 For difficulties in proving a conspiracy under this section, see Garrison v. United States, 135 F. 2d 877 (5th Cir. 1943) ; Logan v. United States, 144 U. S. 263 (1892). But the general criminal conspiracy statute, 18 U. S. C. $\$ 371$ (1948), has been used in conjunction with $\S 242$ to get jurisdiction over private citizens working with the state officers. United States v. Trierweiler, 52 F. Supp. 4 (E. D. Ill. 1943); this section could probably be used to similar advantage.

51 Baldwin v. Franks, 120 U. S. 678 (1887).

52 The penalties of ten years' imprisonment and a $\$ 5,000$ fine make this offense a felony; compare the one year's imprisonment and $\$ 1,000$ fine of $\$ 242$, creating only a misdemeanor. Text at note 33, supra. See 18 U. S. C. \$ 1 (1948) (defining felony and misdemeanor). A penalty of even greater severity, disqualification from federal office, was removed from the statute at the request of the Department of Justice upon reenactment of the section in the new Criminal Code. Revisor's Notes $\S 241, \mathrm{U}$. S. C. Congressional Service 2468 (1948). See generally CARR, op. cit. supra note 30, 59-60. As the offense in $\S 242$ is only a misdemeanor, the new general criminal conspiracy statute, 18 U. S. C. $\$ 371$ (1948), provides only the same penalty. The former criminal conspiracy statute, 14 STaT. 484 , as amended, 18 U.S.C. $\$ 88$ (1946) conld be used to make the crime a felony and increase the imprisonment to two years.

53 Compare § 242 , text at note 32 , supra.

54 See discussion of Screws v. United States, text at note 40 , supra. Williams v. United States, 179 F. 2d 644, 647-648 (5th Cir. 1950) holds that no crime is committed under $\$ 241$ if the victim has not been "willfully" deprived of a "lnnown" federal right, in the meaning of the Screws case. Text at note 42, supra. To "conspire" to deprive is not enough.

65 In Classic v. United States, supra note 34, the section was applied to protect rights in federal primary elections with httle discussion, by the majority, of the intent required.

56 But cf. Wilhams v. Umited States, supra note 54, where it was held that this section did not protect Fourteenth Amendment rights and hence did not punish beatings and false imprisonment by municipal officers, activities analogous to searches and seizures. It was said that the statute protected only the rights of citizens derived from national citizenship, such as the right to vote in federal elections. Also see the dissent of Justice Douglas, concurred in by Justices Black and Murphy, in Classic v. United 


\section{U.S. C. $\S 43^{57}$ provides:}

Every person who, under color of any statute, ordinance, regulation, custom, or usage, of any State or Territory, subjects, or causes to be subjected, any ... . person . . . to the deprivation of any rights, privileges, or immunities secured by the Constitution and laws, shall be liable to the party injured in an action at law, suit in equity, or other proper proceeding for redress.

This statute is similar to the corresponding criminal section in its "color of law" requirement. 58 But "void for vagueness" objections, which arise in civil as well as in criminal cases, ${ }^{60}$ tend to be more lightly regarded in civil cases ${ }^{60}$ As an illegal search and seizure is probably committed under "color of law," ably be preserved against objections of vagueness by reading in a requirement of "willful" misconduct. So far this section has been utilized mainly in equal protection cases; ${ }^{62}$ although an unreasonable search and seizure could conceivably involve the "purposeful discrimination" required for a violation of the equal protection clause, ${ }^{03}$ a due process theory appears a sounder basis. Thus, it can be concluded that Section 43 provides sufficient possibility of relief to warrant consideration. ${ }^{64}$

States, supra note 34 , at 329 , that this section should be confined to offenses "clearly" embraced within it-which do not include violation of the right to bave a vote counted in a federal primary. Also see dissent in United States v. Saylor, 322 U. S. at 390 (1944) and the Screvers dissent. Text at note 46, supra.

5517 STat. 13 (1871).

58 "Color of law" means the same in both the criminal and civil statutes. Picking v. Pennsylvania R.R., supra note 28; Burt v. New York, 156 F. 2d 791 (2d Cir. 1946); McShane v. Moldovan, supra note 37. See text at note 34, stupra, for the requirement in the analogous criminal statute.

59 Small Co. v. American Sugar Refining Co., 267 U. S. 233 (1925), distinguishing Levy Leasing Co. v. Siegel, 258 U. S. 242 (1922).

60 See Note, 30 CarTf. L. REv. 677, 678 (1942).

61Text at note 36 , supra.

62 E. g., Snowden v. Hughes, 321 U. S. 1 (1944); Burt v. New York, supra note 58; Gordon v. Garrson, 77 F. Supp. 477 (E.D.Ill. 1948).

63 Cf. Snowden v. Hughes, supra note 62; Burt v. New York, supra note 58. See Burt v. New York, supra, and Gordon v. Garrson, supra note 62, for successful con1plaints for purposeful discrimination committed against single individuals. But $c f$. Mitchell v. Greenough, 100 F.2d 184 (9th Cir. 1938).

Also see 12 STAT. 284 (1861), as amended, 8 U.S.C. $\$ 47$ (1946) (conspiracy to deprive of equal protection) and 17 STAT. 15 (1871), 8 U.S.C. $\$ 48$ (1948) (failure to halt such conspiracy) for other remedies based upon an equal protection theory. The latter statute might be applicable to some cases of non-action by superior officers resulting in illegal search and seizure.

64 These civil remedies offer special advantages in that they can be used against those public officers who are given immunity from civil suit under state law. Picking v. Pennsylvania R. R., supra note 28 (common law immumity of judge and state executive officers and statutory immunity of governor overridden by terminology in federal statutes applying to all persons). Cf. Ex parte Virgimia, supra note 28 (common law immunity of judge for non-ministerial acts held no bar to criminal prosecution). 


\section{Suppression and Recovery of Illegally Seized Evidence in California}

The safeguards against unreasonable search and seizure afforded by state law will now be examined to determine whether state procedures are adequate to protect the right.

In California, as in most states, the defendant has no right to suppress illegally obtained evidence by motion $^{65}$ or injunction. ${ }^{66}$. But the California courts allow a civil action to recover the evidence even though a criminal court is making current use of it. ${ }^{67}$ The result is that the state practice differs from the federal exclusionary rule in two respects. First, federal courts hold illegally seized evidence immune from civil process. ${ }^{68}$ Second, if a California court is compelled by civil process to return evidence, "leads" gained from the descriptions of the seized property are admissible in the prosecution; ${ }^{69}$ by federal law, on the other hand, suppression of evidence upon timely motion prohibits any reference at the trial to the evidence or to "leads" which it may have furnished."

Property held by police or prosecuting authorities of the state is recoverable by claim and delivery, ${ }^{71}$ while judicial officers, who are

65 People v. Mayen, 188 Cal. 237, 205 Pac. 435 (1922), discussed in Grant, Search and Seizure in California, 15 So. CalrF. L. Rev. 139, 146-152 (1942); People v. Kelley, 22 Cal. 2d 169, 137 P.2d 1 (1943) ; People v. Gonzales, 20 Cal. 2d 165, 124 P. 2d 44 (1942), cert. denied 317 U.S. 657 (1942); People v. One 1941 Mercury Sedan, 74 Cal. App. 2d 199, 168 P.2d 443 (1946); People v. Richardson, 83 Cal. App. 302, 256 Pac. 616 (1927), cert. denied 276 U.S. 615 (1927). Cf. Munson v. Munson, 27 Cal. 2d 659, 166 P. 2d 268 (1946) (evidence illegally seized by private party and used to prove unfitness of a parent as guardian); Herrscher v. State Bar, 4 Cal. 2d 399, 49 P. $2 d 832$ (1935) (evidence illegally seized by private party and used in disbarment proceedings); People v. Alden, 113 Cal. 264, 45 Pac. 327 (1896) (judgment roll illegally seized froun the state). See generally, Wolf v. Colorado, supra note 1 at 33-38 (tabulating states); People v. Defore, 242 N. Y. 13, 150 N. E. 585; 8 Wrgmore, Evmence $\$ 2183$.

68 (3rd ed. 1940). Chierotti v. San Francisco Police Department, 20 Cal. 2d 895, 124 P. 2d 51 (1942), a coinpanion case to People v. Gonzales, supra note 65, adopting the reasoning of that ease.

67 Stern v. Superior Court, 76 Cal. App. 2d 772, 174 P. $2 d 34$ (1946). See People v. Mayen, sutpra note 65 at 251-252, 205 Pac. at 441 ; Ryan v. Crist, 23 Cal. App. 744, 139 Pac. 436 (1914).

68 Grant, supra note 9, 153.

69 See Stern v. Superior Court, supra note 67 at 782, 149 P.2d at 39; People v. Guido, 93 Cal. App. 478, 479-480, 269 Pac. 670 (1928). Cf. People v. Gonzales, supra note 65; Chierotti v. San Francisco Police Departnent, supra note 66; Grant, supra note 9, 151-152.

70 Silverthorne Lumber Co. v. United States, 251 U. S. 385 (1920). Grant, supra note 9,152 .

$\pi$ Atlas Finance Corp. v. Kenny, 68 Cal. App. 2d 504, 157 P.2d 401 (1945); Silva v. MacAuley, 135 Cal. App. 249, 26 P. 2d 887, 27 P. $2 d 791$ (1933). See People v. Mayen, supra note 65 at 251, 205 Pac. at 441; Gardiner v. Frederickson, 70 Cal. App. 677, 679, 234 Pac. 117, 118 (1925); Ryan v. Crist, supra note 67. Note that seized property is presumed to lave been taken before the police magistrate. Collins v. Lean, $68 \mathrm{Cal}$. 284, 9 Pac. 173 (1885). If the suit is against superior officers, it must be alleged that the seizing officers acted on behalf of their superiors in order to eliminate the possibility that the seizing officers acted in a private capacity. Gardiner v. Frederickson, supra. CAr. Crv. CoDE $\$ 3380$ providing for specific delivery, is another possible basis of recovery. Note, 36 CAIIF. L. REv. 647 (1948). 
immune from the provisional remedy, are properly reached by mandate. ${ }^{2}$ However, even though the proper proceeding is used, return is refused if the property is such that possession thereof would violate public pohicy. ${ }^{73}$

\section{Criminal Prosecution of Seizing Officer}

Criminal prosecution of a public officer is a dubious means of obtaining satisfaction and deterring unlawful search and seizure. Although statutes cover misuse of process by a public officer, ${ }^{74}$ malicious procurement of a search warant or warrant of arrest without probable cause, ${ }^{75}$ and false imprisonment, ${ }^{\text {T6 }}$ no prosecution of a public officer under these statutes has been found which has reached an appellate court. ${ }^{77}$ As abuse of criminal process by public officers is probably common, ${ }^{\text {i8 }}$ this may seen unusual. It would be even more unusual, however, for a district attorney to prosecute his associates or co-workers, or to find a jury which would convict for acts of law enforcement, especially when the acts have resulted in the discovery of crime.

\section{Suit for Damages}

Despite certain exculpatory statutes, ${ }^{79}$ there are linited opportunities for a tort action in California to redress an illegal search and seizure. The greatest obstacle is the likelihood that, although a cause of action will exist, damages recoverable will be so insubstantial that suit will not be worthwhile. Nevertheless, possibilities of success are

72 Stern v. Superior Court, supra note 67. At least in action against a police magistrate, facts showing his possession must be alleged. Gardiner v. Frederickson, supra note 71. But cf. Colhins v. Lean, supra note 71.

73 Collins v. Lean, supra note 71 (lottery tickets); Niccoli v. McClelland, 21 Cal. App. 2d 759, 65 P. 2d 853 (1937) (chain letters); Fon v. Chambers, 68 Cal. App. 244, 228 Pac. 865 (1924) (lottery tickets). Lottery prizes are subject to forfeiture to the state by an action in rem. CAL. PEN. CODE \$ 325. See Niccoli v. McClelland, sicpra at 764, 65 P. 2d at 856. The return of narcotics and opium pipes is prevented by CAL. Health AND SafeTY Code $\S \S 11650-11657$. But if any lawful use of the property is possible, its return can be compelled. Cf. Atlas Finance Corp. v. Kenny, stupra note 71 at 512,157 P. 2d at 405 (gambling devices).

74 Car. Pen. Code \& 146.

75 CaL. PEN. Code $\$ 170$.

T6 Cal. Pen. Code $\$ 236$.

i7 Accord, 8 CALTE. L. Rev. 347, 349 n. 11 (1920).

78 E. g., People v. Mayen, stepra note 65 ; Ware v. Dunn, 80 Cal. App. 2 d 936, 183 P. 2d 128 (1947); Silva v. MacAuley, stcpra note 71; McAlmond v. Trippel, 93 Cal. App. 584, 269 Pac. 937 (1928). Yankwich, supra, note 24, 17.

79 CaL. Govt. Code $\$ 1955$ immunizes an officer who enforces in good faitb and without málice a law later declared unconstitutional. CAL. PoL. CoDE § 4168: "A sheriff or other ministerial officer is justified in the execution of, and must execute, all process and orders regular on their face and issued by competent authority, whatever may be the defect in the proceedings upon which they were issued." 
probably greater than is thought by those who would despair of any recovery. ${ }^{80}$

Damages closely related to the wrongful act are recoverable; damages to the seized property ${ }^{81}$ and the house, ${ }^{82}$ reasonable costs of pursuit of the property, ${ }^{83}$ and mental suffering caused by the invasion of the right of privacy ${ }^{84}$ are items of damage which would be recoverable regardless of conviction. ${ }^{85}$ But, if the damage to the property interest is trivial, actual damages will be substantial only if the right to privacy is generously protected. The public policy which allows the prosecutor to use illegally seized evidence ${ }^{86}$ probably requires the conclusion that any damages caused by conviction such as loss of freedom, reputation, and earning power are too "remote." 87

If actual damages are insubstantial, the plaintiff must rely upon punitive damages for an effective recovery..$^{8}$ Although punitive damages are awardable for malicious or wanton interferences with property rights, ${ }^{89}$ their recovery in cases of unlawful search and seizure must be considered unlikely, except in particularly outrageous situations. Since pumitive damages are awarded only in the discretion of

80 For successful recoveries, see Noack v. Zellerbach, 11 Cal. App. 2d 186, 53 P. 2d 986 (1936) ; Silva v. MacAuley, supra note 71 ; San Francisco Chronicle, April 19, 1950, P. 1, col. 6, for a $\$ 3,000$ recovery against two police officers for false arrest. See Yankwich, supra note 24,25 , for the view that the right to damages is of neghible value.

81 Silva v. MacAuley, supre note 71 (conversion and destruction of crabs and conversion and wrongful detention of truck by illegal search and seizure) citing CaI. Crv. CODE \& 3336, which provides that the measure of damages for conversion is either the value of the property and interest from the time of conversion or all damages "proximately" caused that were not reasonably avoidable.

82 See Prosser, ToRTs 82 (1941), where it is said that a trespasser is liable for all damage "proximately" caused to the property although such damage could not reasonably bave been anticipated.

83 CAL. Crv. CODE $\$ 3336$.

81 This right is recognized in California. Melvin v. Reid, 112 Cal. App. 285, 297 Pac. 91 (1931). See Prosser, op. cit. supra note 82, at 1054-1055. No proof of special damages is needed.

85 Entick v. Carrington, 19 How. St. Tr. 1030, 95 Eng. Rep. 807 (1765).

88 See People v. Mayen, supra note 65 at 251,205 Pac. at 441 , for an extreme statement of the importance of this policy in California.

87 CAI. Crv. CoDE \& 3359: "Damages must, in all cases, be reasonable and where an obligation of any kind appears to create a right to unconscionable and grossly oppressive damages, contrary to substantial justice, no more than reasonable damages can be recovered." See PRosSER, op. cit. supra note 82, at 865-866, for the analogous situation of the immunity of the complaining witness and of the public prosecutor from suit for malicious prosecution, based upon the public interest in unhindered criminal prosecution.

CAI. Crv. CoDE $\$ 3336$ limits damages for conversion to what is "natural, reasonably, and proximate result." A sufficiently "direct" causation will be nore readily discovered, however, in the case of an intentional tort. PROSSER, op. cit. supre note 82, at 39-40; McCorarrcr, Damages 263-264 (1935). See, for "proximate cause" limitations on recovery on surety bonds in negligence cases: Oakland Bank of Savings v. Murphy, $68 \mathrm{Cal}$. 455, 9 Pac. 843 (1886). Riverside Portland Cement Co. v. Maryland Casualty Co., 46 Cal. App. 87, 189 Pac. 808 (1919).

88 CAL. CIv. CODE $\$ 3294$ recognizes a right to punitive ("exemplary") damages.

89 Prosser, op. cit. supra note 82, at 11-13. 
the jury, ${ }^{90}$ a convicted felon, or even an innocent citizen, may have difficulty in obtaining such damages from the overzealous public officer. The requirement of evil motive, or willful or wanton conduct ${ }^{91}$ protects an officer who acts in good faith, with law enforcement as the primary motive. ${ }^{22}$ Pumitive damages, moreover, are not recoverable in suits on judicial and indemnity bonds ${ }^{03}$ or in actions against a sheriff vicariously liable for his deputies ${ }^{94}$ unless the sheriff has "ratified" the tort. ${ }^{95}$ Thus, although an action may be maintainable against a financially responsible defendant, in the many cases in which the plaintiff's property is of inconsequential value the remedial and deterrent effects of the action depend upon the jury's sentiments as to unlawful official conduct as manifested in the awards for invasion of privacy and pumitive damages. If, as will often happen, these intangible items are given little weight as against the value of law enforcement, the plaintiff will be without an effective recovery in tort. But when the plaintiff has a cause of action that is worth pursumg, this type of tort action has advantageous features: (1) the apphicable presumptions; (2) the possibility of a suit on surety bonds of the public officer; and (3) the financial responsibility of superior officers who may be successfully sued for the torts of those under their authority.

Plaintiff probably has the advantage of a presumption that the search and seizure was unlawful. Penal Code section 236, the general false imprisonment section, has, in prosecutions of private individuals, been construed to make any arrest presumptively illegal, ${ }^{06}$ and it seems possible that Penal Code section 146, the general misuse of process section, which covers search and seizure as well as false arrest, will be similarly construed. ${ }^{2 i}$ This presumption has also been applied in civil suits for false arrest. ${ }^{98}$ There is a contrary set of presumptions, however, which go to sustain the legality of the acts of a

90 Prosser, Torts 11 n.48.

91 CAL. Crv. CODE § 3294 requires "oppression, fraud, or malice, express or implied."

92 E.g., Silva v. MacAuley, supra note 71, for an error in good faith on the extent of a state statute allowing the seizure.

93 MCCorancK, Damages 291 (1935); Note, 64 A. L. R. 934 (1929).

94 See cases cited infra note 117.

95 Although ratification may be evidenced by a failure to fire the deputies, it must occur upon more substantial notice of the tort than mere service of process in the tort action. Foley v. Martin, 142 Cal. 256, 71 Pac. 165, 75 Pac. 842. See Noack v. Zellerbach, 11 Cal. App. 2d 186, 190, 53 P. 2d 986, 989 (1936) for a suggestion that an officer liable only for "direction" of or for "co-operation" in the tort may be held by "ratification."

96 People v. Perry, 79 Cal. App. 2d 906, 180 P.2d 465 (1947) (prosecution for resisting arrest); People v. Agnew, 16 Cal. 2d 655, 107 P.2d 601 (1940).

07 Cf. People v. Perry, supra note 96 at 913, 180 P. 2d at 469.

98 Mackie v. Ambassador Hotel \& Investment Corp., 123 Cal. App. 215, 11 P. 2d 3 (1932) (arrest directed by a police officer not a party to the appeal). 
public officer and which may "overcome" the presumption of illegality. ${ }^{99}$

If the public officer has given a surety bond, in certain circumstances the plaintiff will have the good fortune of an action against the surety. Counties are required to bond the sheriff, constable, district attorney, and justice of the peace. ${ }^{100}$ Municipalities with freeholders charters, which include the larger cities, ${ }^{101}$ and those with special charters ${ }^{102}$ are not required by general law to bond any public officers. Mumicipal Corporation Bill cities ${ }^{103}$ of the fifth class, only two in number, ${ }^{104}$ are required to bond the town marshal, city attorney, clerk, and treasurer, ${ }^{105}$ while cities of the sixth class, comprising the great majority of smaller communities, ${ }^{106}$ are required to bond only the clerk and treasurer. ${ }^{107}$ All other officials, including those who would ordinarily be concerned with the enforcement of the criminal law, need be bonded only at the discretion of the city council. ${ }^{108}$ As bonding of municipal public officers is prevalent, ${ }^{109}$ the applicable charter and ordinances should be examined. ${ }^{110}$ If the officer has furnished such a bond to indemnify the city, the plaintiff has a direct right of action against the surety in cities incorporated under the Municipal Corporation Bill ${ }^{111}$ and in those cities with freeholders charters ${ }^{112}$ which specifically mcorporate general state law on this subject. ${ }^{113}$

99 Cax. Code Civ. Proc. $\$ 1963$ (15), (16), (33). But cf. People v. Perry, supra note 96.

100 CaL. Govt. Code $\$ 24150$.

101 See Peppin, Municipal Home Rule in California, 30 CarxF. I. Rev. 1, 41, Appendix A (1941) for a list of the freeholders charter cities of California, as of October, 1941.

102 Id. 44, Appendix C (1941) for a list of the special charter cities of California. 1032 CaL. GeN. Laws 1811-2001 (Deering 1944).

104 Santa Ana and Woodland. Peppin, supra note 101 at 329, Appendix E. This appendix contains a table for determining the classification of California cities as of March 1942. Cities were never incorporated under classes one, two, and three, and, under four, two were incorporated for a short time only. At the 1949 session of the legislature, upon the inclusion of the Municipal Corporation Bill into the Government Code, these four classes were abolished.

105 CAL. Govt. CODE $\$ 36624$.

100 See Peppin, supra note 101 at 42, Appendix B, for a list.

107 Car. Govr. CODE $§ 36518$.

108 CaL. Govt. Code $\$ 36518$.

10918 CAL. Jur. 982 (1924).

110 E.g., Fernelius v. Pierce, 22 Cal. 2d 226, 138 P. 2d 12 (1943).

111 Wood v. Lehne, 30 Cal. App. 2d 222, 85 P. 2d 910 (1938), based on CaL. Govt. CODE $\S 1550$, which reads a liability to third persons into the contract of surety. See $\S 753$ and $\S 853$ of the Municipal Corporation Bill, supra note 103, the pertinent parts of which now appear in CAI. Govr. CODE $\$ 36521$ and $\$ 36626$, respectively. See Peppin, supra note 101, 281 n.24.

112 See note 101, supra, for reference to a list of freeholders charter cities.

113 Fernelius v. Pierce, supra note 110, liberally construing the Oakland city charter to embrace CAL. Govt. Code $\$ 1550$ (CAc. Pox. Code $\$ 961$ ) and other general law relating to the bonding of public officers. The section was enacted into the Government Code in 1943 after the Fernelius case and the general tern "city" replaced specific references to cities and towns organized under the Political Code and to those gov- 
In other cities, ${ }^{114}$ the surety's liability is governed by the local charter or by the common law rule which denies recovery to a third person on the municipality's bond. ${ }^{115}$

As the plaintiff wants to reach those who, by bond or otherwise, are able to pay substantial damages, it is important to determine how far public officers are liable for the acts of their subordinates. There are four theories by which the California courts have found this liability. The superior has "directed" the subordinate; 116 is "identified" with him; ${ }^{117}$ has "co-operated" with him; ${ }^{118}$ or has been "negligent" im hiring or firing. ${ }^{118}$ Recent developinents indicate an increas-

erned by freeholders charters. Although it would seem that only a simplification of language was intended, the section as it now stands has not yet been construed. On charter provisions incorporating general law, see Peppin, sutpra note 1001 at 325 n.148.

114 Special charter cities are probably only subject to general state law if they have specifically incorporated it in their charters. Peppin, supra note 101, 273, 280, 288. See note 102, supra, for reference to a list of special charter cities.

115 Sunter v. Fraser, 194 Cal. 337, 228 Pac. 660 (1924); Municipal Bond Co. v. Riverside, 138 Cal. App. 267, 32 P. 2 d 661 (1934); Carr v. Knoxville, 144 Tenn. 483, 234 S.W. 328, 19 A. L. R. 69 (1921). California freeholders charter cities have exclusive legislative competence in respect to "municipal affairs," and the bonding of municipal officers has been held to be a "municipal affair." Sunter v. Fraser, supra; Municipal Bond Co. v. Riverside, supra. See Wood v. Lehne, supra note 111 at 225,85 P. 2d at 912. Of course, the municipality is not liable for acts perforned as a governmental function. Municipal Bond Co. v. Riverside, supra.

116 Michel v. Smith, $188 \mathrm{Cal} .199,205$ Pac. 113 (1922); Hilton v. Oliver, $204 \mathrm{Cal}$. 535, 269 Pac. 425 (1928); People v. Standard Accident Insurance Co., 42 Cal. App. 2d 409, 108 P. 2d 923 (1941); Reed v. Molony, 38 Cal. App. 2d 405, 101 P. 2d 175 (1940); Downey v. Allen, 36 Cal. App. 2d 269, 97 P.2d 515 (1939); Van Vorce v. Thomas, 18 Cal. App. 2d 723, 64 P. 2d 772 (1937); Bower v. Davis, 13 Cal. App. 2d 678, 57 P. $2 d$ 574 (1936); Noack v. Zellerbach, 11 Cal. App. 2d 186, 53 P. 2d 986 (1936). These cases involve those public officers whose subordinates hold a separate public office, as did the subordinates of a police chief in the Michel case, supra. See Van Vorce $r$. Thomas, supra, for an analysis of what is a separate public office. The cases refuse to hold the superior to the strict liability of a principal in an agency relationship on the theory that the subordinates are public employees wloo are as responsible to the people as is the superior.

115 Foley v. Martin, 142 Cal. 256, 71 Pac. 165, 75 Pac. 842 (1904); Ross v. Sweeters, 119 Cal. App. 716, 7 P. 2d 334 (1932); Abbott v. Cooper, 218 Cal. 425, 23 P. 2d 1027 (1933), cited but not followed in Van Vorce v. Thomas, supra note 116. These cases involve those officials (sheriffs and constables) who have personal representatives or "deputies." The deputy "partakes" of the "identity" of the officer; therefore, the officer is tiable for the acts of the deputy as though they were his own. Compare note 116.

118 Wood v. Lehne, supra note 111. Cf. Kenyon v. Hartford Accident \& Indemnity Co., 86 Cal. App. 269, 260 Pac. 952 (1927). See Michel v. Smith, supra note 116 at 201, 205 Pac. at 114; Hilton v. Oliver, supra note 116 at 539-540, 269 Pac. at 426; Bower v. Davis, supra note 116 at $679-680,57$ P.2d at 575 . The Wood case holds that the "falsity" of an arrest continues throughout to make hable all those who "cooperate" therein (police chief held liable for participating in incarceration after false arrest). The same principle prohably applies to the law of search and seizure in California. See Michel v. Smith, supra note 116 at 201, 205 Pac. at 114. But the official who acts without discretionary power and without malice is not bable on this theory. Wood v. Lehne, supra (desk sergeant who "hooked" plaintiff at the direction of a superior).

110 Fernelius v. Pierce, supra note 110 . See Hilton v. Oliver, supra note 116 at 539, 540, 269 Pac. at 426; People v. Standard Accident Co., sufra note 116 at 411, 108 P. $2 \mathrm{~d}$ at 925 .

One caution should be observed when proceeding against any public officer on 
ing readiness to impose liability upon superior officers. The vicarious liability of a sheriff or constable for the deputy with whom he is "identified" has recently been reaffirmed and extended by the supreme court to hold a county clerk and lis surety liable for the acts of a deputy. ${ }^{120}$ And the negligence concept can be used to hold a city manager, police chief, and their bondsmen for the torts of unfit policemen who are negligently permitted to be hired and retained. ${ }^{121}$ The tendency is to minimize the importance of such statutory regulation of liring and firing as civil service restrictions, ${ }^{122}$ which, in the past, lave been emphasized in exculpating the superior. ${ }^{123}$

Once a judgment is rendered, the plaintiff has, against inost public officers, the special advantage of enforcing it against their salaries by a procedure in the nature of garnishment. ${ }^{124}$ Subject to the usual salary exemption, ${ }^{125}$ a procedure exists whereby upon delivery of an abstract or transcript of a judgment to a state office or to the auditor of a local subdivision of the state, the officer's salary will be paid into

this theory. In negligence cases involving public officers, CAI. GovT. CODE \$, 1981 requires a verified claim in writing to be filed within 90 days. Failure to file bars the action. See generally, Ward, Requirements for Filing Claims Against Governmental Units in Californic, 38 Calif. L. Rev. 259 (1950).

120 Union Bank \& Trust Co. v. Los Angeles, 11 Cal. 2d 675, 81 P. 2d 919 (1938), relying on CAL. Govt. CODE $\$ 1504$ : "Every official bond . . . is . . . obligatory upon the principal and sureties therein for: (a) Any and all breaches of the conditions thereof ... whether such breaches are committed or suffered by the principal officer, his deputy, or clerk." See, for broad applications of this statute, 1 OPS. ATr'y. Gen. 78 (1943); 5 OPs. ATT'Y. GEN. 114 (1945) ; 11 OPs. ATT'Y. GEN. 159 (1948). As the bonding of municipal officers is a municipal affair, this statute would not apply to freeholders charter cities which bave not expressly subjected themselves to general law. See note 115, supra. See Hartford Accident \& Indemnity Co. v. Tulare, 30 Cal. 2d 832, 836-837, 186 P. 2d 121, 123-124 (1947) for the application of this section by a cliarter provision making general law applicable.

121 Fernelius v. Pierce, supra note 110, citing REstatenent; TORTs $\S 307$ (1934) (negligence in use of instrumentality of known incompetence). Remedies were held to exist upon a $\$ 50,000$ bond of the city manager and a $\$ 5,000$ bond of the police chief. This theory of action is of the greatest importance; it imposes a duty upon top echelon municipal officials to rid the city of malicious subordinates and allows one injured by a negligent failure to perforn this duty redress against financially responsible persons.

122 Union Bank \& Trust Co. v. Los Angeles, supra note 120, disapproving Lorah v. Biscailuz, 12 Cal. App. 2d 100, 54 P. 2d 1125 (1936); Fernelius v. Pierce, supra note 110. See Prosser, TORTS $472-473$ (1941) for the view that the modern theory of vicarious liability is based upon the allocation of insurable risks to the one better able to bear them. In the Fernelius and Union Bank cases, sureties were co-defendants.

${ }^{123}$ Cf. People v. Standard Accident Insurance Co., supra note 116; Lorah v. Biscailuz, now disapproved, supra note 122.

124 CAL. CODE Crv. Proc. § 710. The only officers exempted from this procedure, by Car. Code Civ. Proc. $\$ 710$ (f), are those whose salaries are fixed in Cax. Const. ArT. V, § 19-the Governor, Lieutenant Governor, Secretary of State, Controller, Treasurer, and Surveyor General. Although the Attorney General is so listed, it has been intimated that he may be outside the exemption, his salary also being affected by $\$ 21$ of the same article. Wilson v. Walters, 19 Cal. 2d 111, 114, 119 P. 2d 340, 342 (1941).

${ }_{125}$ CAL. CODE Crv. PROC. \& 690.11 (reasonable support for debtor and family from earnings from personal services). Low-salaried officers who are usually the personal participants in the tort and thus unore readily leeld liable may gain complete exemption under this statute. 
court. Upon determination of the sums exempt from execution, the court then pays the remainder to the judgment creditor. ${ }^{126}$

\section{Injunction and Prohibition}

Extraordinary remedies may be available in California to prevent a threatened search and seizure if there is no adequate remedy to recover possession of the seized property and damages for its detention. The only authority for such a remedy is a dictum ${ }^{127}$ and Wirin $v$. Horrall, ${ }^{128}$ where a taxpayer's suit prevented a multiplicity of actions by enjoining the Los Angeles police from using city funds to conduct the so-called "police blockades"-the indiscriminate searching of vehicles and pedestrians within selected areas.

\section{CONCLUSION}

Is there sufficient protection against illegal search and seizure by state officers in California? The answer in any given case depends upon a fortuitous set of circumstances-proof of substantial damage, the attitude of the jury in giving punitive damages, the participation of higher officers financially more responsible, and the ability of the individual defendant to respond in damages. These elements weigh heavily against the plaintiff, and although one fortunately situated may gain an adequate recovery, it seems clear that present protection is insufficient to secure respect for the right. Even the exclusionary rule, by itself, would be inadequate to protect those who are innocent of crime. What is needed is a better remedy.

The definition of unreasonable search and seizure in California, for the most part, adequately delineates the right, even without the aid of federal law. In spite of possible federal remedies, it is submitted that illegal search and seizure, in normal circumstances, ${ }^{120}$ is a local problem best suited for a local solution. Educational procedures and better civil service methods for selection and promotion of law enforcement officers will help. But to vitalize the guarantee the California legislature, in aid of the search and seizure provision of the

126 Wilson v. Walters, supra note 124, upheld the constitutionality of this procedure and disapproved Gamble v. Utley, $86 \mathrm{Cal}$. App. 414, 260 Pac. 930 (1927) which restrictively interpreted the statute. Cf. Lay v. Hammond, $212 \mathrm{Cal} .665,300 \mathrm{Pac} .10$ (1931) and Weiser v. Payne, 110 Cal. App. 378, 294 Pac. 407 (1930), both based on an carlicr, more restrictive statute. The statute extends to all municipahties, including frecholders charter cities. Wilson v. Walters, supra note 124.

${ }^{12 \pi}$ See Ryan v. Crist, 23 Cal. App. 744, 744-745, 139 Pac. 436 (1914); Grant, supra note 9 , 153-154.

12885 Cal. App. 2d 497, 193 P. 2d 470 (1948).

${ }^{129}$ See Hague v. C.I.O., 307 U.S. 496 (1939) for an example of abnormal circumstances in which federal enforcement of the right would be highly desirable. There existed a conspiracy by the local authorities to thwart labor organization by a complete deprivation of civil rights, including the guarantee against illegal search and seizure. 